\title{
BASIC PROVISIONS GOVERNING DURATION OF LEASE
}

\author{
R. J. BALFOUR*
}

\section{Basic Conveyancing Devices}

At the outset it is to be noted that this paper will not deal with what are termed "top documents"- that is, fee simple titles, fractional interest titles or long-term leases which have been taken "on top of" conventional petroleum and natural gas leases. Nor will consideration be given to the position of the raliway companies, the Hudson's Bay Company and the several "colonization" companies, each of which holds large areas of mineral lands in fee simple in western Canada.

\section{(a) Fee Simple Titles}

Under the Torrens System title may issue to "all mines and minerals", "all petroleum and natural gas" or (in Saskatchewan at least) to "all petroleum and natural gas and all other hydrocarbons". Unquestionably the holder of such a title has the right to work the subject minerals. Further, it is clear that there are certain operating advantages if a fee title is secured instead of a lease. For example, there would be no royalties or other lease burdens and there would be no time limit on exploration.

At the same time there are obvious disadvantages in operating under fee titles. In particular, the acquisition cost would, in general, be much greater as compared to the usual landowner's royalty payable under a lease, and would undoubtedly increase as interest in the area intensified through discoveries and competitive buying. A further disadvantage from the point of view of both the landowner and the petroleum industry arises from the fact that where there are long-term dispositions there is no incentive for early exploration and development.

\section{(b) Long-Term and Renewable Leases}

Many of the considerations encountered in dealing with fee simple titles also apply to long-term and renewable leases. The advantages to the exploration company are obvious. The difficulties of negotiation are, however, formidable and, if anything, the trend is to shorten rather than lengthen the term of petroleuf and natural gas leases. The modern lease adjusts readily to the rapid shifts of value frequently found in the petroleum industry, and in making these adjustments the trend is to reduce the term in order to avoid the heavy bonuses and other burdens which would otherwise have to be paid in order to acquire land in highly competitive situations.

In summary then, the above considerations have lead to the widespread use of petroleum and natural gas leases of a relatively short term.

* Balfour, MacLeod, McDonald, Laschuk \& Kyle; assisting in the writing of the paper were: Professor R. C. Carter, University of Saskatchewan; R. B. Laschuk, Balfour, McLeod, McDonald, Laschuk \& Kyle, Regina; W. M. Loewen, Francana Oil \& Gas Ltd. Regina; E. J. Moss, Moss \& Wimmer, Regina; B. V. Reed, McPherson, Leslie \& Tyerman, Regina; T. C. Wakeling, McDougall, Ready \& Wakeling, Regina. 
2. An Analysis of the Functions Performed by Specific Clauses of the Lease and the Problems of Duration That They Present

\section{(a) The Habendum Clause and Drilling Clauses}

Early leases (commencing in the 1860's) were drawn to endure for the estimated period of profitable production. A period of twenty years was not uncommon, although it varied from ten to ninety-nine years. ${ }^{1}$ A sample of an early lease reads as follows:

$\ldots$ he is to continue to enjoy the privileges until it is determined whether there is oil to be found there or not. If it is found in sufficient quantities to justify working, the lease is to continue for twenty years . .. ${ }^{2}$

A consideration of its content gives a hint as to the nature of the ensuing struggle between lessor and lessee. Under such a lease the lessee had perhaps an unlimited time in which to explore for the oil but, having found it, he could only participate in the production for twenty years even though production might continue for a longer period.

It is not necessary to detail the developments in the leases used in the industry up to the modern form of petroleum and natural gas lease. ${ }^{8}$ It is not surprising, however, to see that over the years a compromise has been worked out which provides, for the benefits of the lessor, (a) a primary term that is usually not more than ten years, and (b) delay rentals over the period of the primary term. Both encourage early exploration work by the lessee and limit the period during which the lessor's petroleum and natural gas rights are tied up. Similarly, for the primary benefit of the lessee, a "thereafter clause" such as, "and as long thereafter as the leased substances shall be produced" assures the lessee that the lease will be of sufficient duration to permit him to receive the full fruits of his exploratory efforts.

Two variations of the present day lease have developed over the years. Each involves the primary term. They are known as the "unless" lease and the "drill or pay" lease. The distinction between them is so well known it need only be stated briefly." The "unless" drilling clause provides that if a well is not commenced by a specified date (usually the anniversary date of the lease) the lease will terminate unless payment of the stipulated annual delay rental ${ }^{\circ}$ is made. If for any reason the rental is not paid the lease automatically terminates by the force of its own wording. On the other hand, under a "drill or pay" clause the lessee agrees either to drill or to pay a specified amount as delay rental for each year of delay in drilling. Failure to pay this delay rental does not automatically terminate the lease. It continues and the lessor's remedy is based on the covenant to drill or pay.

1 D. E. Lewis, The Canadian Petroleum and Natural Gas Lease, 30 Can. Bar Rev. 970.

2 Brown, The Law of Oil and Gas Leases (see Prologue)

8 An outline of this development in Canada will be found in Mr. Lewis's article (supra foonote 1). The development in the U.S.A. is dealt with in Brown, The Law of Oil and Gas Leases.

- A summary of these types of leases is to be found in Mr. Lewis' article ante $n$. 1 . See also Eastcrest Oil Co. v. Strohschein (1951), 4 WWR 553 at 558 for a clear summary of the situation under an "unless" lease.

s The term "delay rental" is really a misnomer since there is no obligation to pay. Lewis and Thompson, Carradian Oil and Gas, vol. 1 at 104(4). 
The "Unless" Lease

Under an "unless" drilling clause the lessee has three courses of action open to him:

(i) He may drill,

(ii) He may pay the "delay rental", or

(iii) He may do neither-thereby allowing the lease to terminate.

There are a number of cases where this type of clause was considered by the Courts in Ontario, Manitoba and Alberta. On the basis of these cases it seems clear that the wording of the "unless" drilling clause simply effects a limitation upon the interest granted. There is nothing in the way of a covenant or condition. Consequently, on failure to pay the delay rental there is no default. The lease has simply come to an end in the manner contemplated by the clause.

It has been held in a number of American decisions-and suggested in one Canadian case, Rostad v. Andreasson ${ }^{6}$ - that payment of delay rental can be waived by the lessor and therefore that the non-payment of a delay rental does not automatically terminate the lease. This conclusion however, was disapproved of in the Manitoba case of Langlois v. Superior Oil of California Limited ${ }^{7}$ where Williams, C.J.Q.B. set out the following principles to be applied in considering the result of a failure to pay delay rental under an "unless" drilling clause, namely:

(i) On failure to pay the lease terminates automatically pursuant to its own terms.

(ii) Such termination involves no default. Therefore no question of relief from forfeiture can arise.

(iii) The law relating to waiver of forfeiture, or election not to forfeit does not apply as there is no forfeiture which can be waived.

Chief Justice Williams also held that acceptance of delay rental after its due date could not be taken as evidence of a new contract because such a contract, being a grant of a profit a prendre, can only be created by an instrument under seal. It would seem that on this latter point Chief Justice Williams was not entirely correct for it is possible to have a novation even with regard to a profit a prendre so long as there is new consideration.

Apart from cases involving a clear failure to pay delay rental on its due date, other problems involving rental payments may arise, with respect to an "unless" lease. There is a paucity of Canadan authorities in this area. A reference to certain American cases will serve to illustrate the type of problems which may arise. The extent to which Canadian courts may follow these decisions is, of course, open to question. By way of example, in two Texas cases, Hunter v. Gulf Producing Company ${ }^{8}$ and Gulf Producing Company v. Perry ${ }^{9}$ it was held that payment made to the depository bank specified in the lease was sufficient despite the failure of the bank to properly credit the lessor's account. The agency principle was apparently relied upon to achieve this result.

Another problem can arise where the lessee relies on the mails to make payment of the delay rental and the lessor fails to receive it, or 
receives it after the due date, because of non-delivery or miscarriage in the post office. The courts of Oklahoma and Kansas seem inclined to the view that where the lessee is not at fault, equity will not enforce cancellation. In Kays v. Little ${ }^{10}$ the payment was made two days late due to delay in the mail. The court did not allow cancellation because the delay was caused by an intervening factor. A similar conclusion was reached in the Oklahoma case of Oldfield v. Gypsy Oil Company. ${ }^{11}$

The Texas courts have not gone so far in this direction. In Appling v. Morrison $^{12}$ a cheque for rental was mailed in ample time but due to a miscarriage in the mail it did not reach the bank in time. It was held that "as a matter of law, the rental not having been paid on or before the due date, the lease was forfeited by its own terms."

However, in Gloyd v. Midwest Refining Company ${ }^{13}$ the court said:

When the lessee in an "unless" lease in good faith manifests his intention to continue the lease by undertaking to pay rental through a method and by means customarily used in such transactions in ample time for payment to reach the lessor or the agreed depository on or before the due date, but due to accident or mistake such payment fails to reach the lessor in time the lease is not, because of such failure, automatically terminated. This is true, because the acts of the lessee manifest an intention not to terminate the lease.

This statement appears to be representative of the position in the United States.

It seems, however, that Canadian courts may refuse to take such a liberal attitude in the interpretation and application of these clauses. Thus, in Canadian Fina Oil Ltd. v. Paschke $e^{14}$ the clause stipulated that "if operations for the drilling of a well are not commenced within one year from the date hereof" the lease would terminate unless the delay rental was paid. The court construed this provision to mean that the rental had to be paid on or before the day preceding the anniversary date of the lease. In interpreting the word "from" the court took the position that, since time was of the essence in the oil industry, the intention was to include the date of the lease in computing the year and accordingly that actual receipt of the payment on the day preceding the anniversary date was required to continue the term of the lease.

Problems may also arise with respect to the proper party to receive the delay rental where there has been a change of ownership of all or part of the lessor's interest. While there do not appear to be any Canadian authorities on this point, one can perhaps predict that decisions relating to such problems will follow a strict interpretation of the provisions of the lease. Unless there is a departure from the present pattern established in Canada, equitable considerations will have no bearing on the outcome.

\section{"Drill or Pay" Lease}

Turning to the "drill or pay" lease, the important feature which distinguishes it from the "unless" lease is, again, that under the former type a failure to pay the delay rental will not operate to terminate the lease automatically. This feature brought the "drill or pay" lease before the courts in the United States early in its history and eventually lead to the development of the "unless" lease.

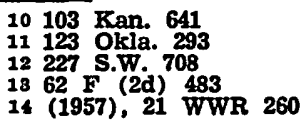


The early history of petroleum and natural gas leases in the United States indicates that the first commercial forms used were "drill or pay" leases running for a definite term of ten or fifteen years. In Brown v. Wilson ${ }^{15}$ the question was raised whether the surrender clause was unilateral and therefore void. The court held that it was not-that since the lease conferred on the lessee a right to surrender, a corresponding right existed in the lessor to compel surrender. Within two years the Supreme Court of Oklahoma overruled this decision. In judgments from Kentucky and other states, however, the lessee's right to surrender a "drill or pay" lease was held to be unilateral and void. As in Oklahoma, later decisions of the Kentucky Court of Appeals held that the surrender provision did not render the lease unilateral and void, and it now appears to be generally accepted that the initial bonus consideration supports all of the provisions of the lease including the surrender clause. In the meantime, and to avoid the question of whether the surrender clause destroyed mutuality, the "unless" clause came into being as a convenient and satisfactory method of dropping the lease should it become desirable to do so.

A further concern which is sometimes expressed in connection with "drill or pay" drilling clauses is that if the lessee fails to drill or pay, and has not surrendered, he may be held to be in default of an obligation to drill. Clearly, this might have serious consequences. It is suggested that the answer to this suggestion lies in the wording of the lease itself, and that under Canadian law, if the relevant provisions of the lease are carefully drawn there can be no question about the right to surrender, and in the absence of a surrender, failure to drill or pay can result in nothing more serious than a claim based on the covenant to pay the accrued rentals.

(b) Transition from Primary Term to the "Thereafter" Clause

The continued existence of a petroleum and natural gas lease of either type may be threatened in different ways during the transition period. An example is found in the recent case of Canada-Cities Service Petroleum Corporation v. Kininmonth ${ }^{16}$ where drilling was commenced prior to the end of the primary term but production was not obtained until after its termination. It was held that such drilling activity did not bring the "thereafter" clause into effect on the strict application of the provisions of the particular lease.

The lesson perhaps to be drawn from a consideration of this case is that a petroleum and natural gas lease will continue to be strictly interpreted by Canadian courts, especially against the lessee. If the process of drilling a well itself is to extend the primary term then it must be spelled out in clear words that this is, indeed, the intent of the parties."

Another problem involving the transition period was considered in the case of Canadian Superior Oil of California v. Kanstrup. ${ }^{18}$ In that case the leased lands were subject to a pooling agreement and the question to be determined was whether production from other lands, also subject to the pooling agreement, was sufficient to continue the lease

1558 Okla, 392

10 (1964), 47 WWR 437 , (S.C.C.)

17 Lewis \& Thompson, Canadian Oil and Gas, 8 105(a).

18 (1964), 47 WWR 129 (Alta. C.A.), applying Gibbard v. Shell on of Canada (1961), 36 WWR 529, (S.C.C.) and Shell of Canada v. Gunderson [1960] S.C.R. 424. 
in question beyond the primary term. It was held, considering the terms of the habendum clause, that it was not and therefore the lease terminated.

If the lease does provide that the drilling of a well or working operations going on at the end of the primary term will extend the lease, it sometimes becomes a problem to determine just what constitutes the commencement of drilling. Canadian courts have not often been called upon to determine what constitutes compliance with the drilling requirement. It seems, however, that they may be ready to follow certain principles more or less established in the United States. In that country the general rule seems to be that actual drilling is unnecessary if substantial preparations have been made towards the commencement of drilling. Illustrations of this rule are found in the Oklahoma cases of Cromwell v. Lewis, ${ }^{19}$ and Smith v. Gypsy Oil Company, ${ }^{20}$ where (a) moving in of timbers for a derrick and digging a cellar and (b) erecting the derrick, moving machinery in and completing a water well, were held to constitute commencement of drilling operations.

The Texas decisions appear to follow this rule and the decisions are similar. It was held in one case that "commence" was to be defined as "to perform the first act of". (See: McAllister v. Texas Company;"1 also Terry v. Texas Company, ${ }^{22}$ and Wheelock v. Batte. ${ }^{23}$ ) However, in Dunbar v. Fuller, ${ }^{24}$ the impossibility of obtaining pipe due to wartime regulations was held not to be a ground for delay in drilling.

In addition, the lessee must be diligent in his operations and in commencing actual drilling operations. This is illustrated by such cases as Phillips v. Berg, ${ }^{25}$ where hauling of sand and cement to the wellsite was held not to be a commencement of drilling operations when actual drilling was not started for nearly four years.

Accordingly, the United States cases seem to hold that there may be a "commencement" within the proper time provided that the operations are conducted diligently and there is no delay in starting actual drilling. Also, the lessee must act in good faith in beginning and continuing his operations. The application of these principles is found in the Canadian cases of Wetter v. New Pecalta Oil Company ${ }^{26}$ and Risvold and Mallory v. Scott and Granville Oils Ltd. ${ }^{27}$

In the Wetter case, the Alberta Court of Appeal allowed an action by the lessor for a declaration that the lease was null and void, holding that the work done in purported compliance with the drilling operation requirements was a mere pretence. Furthermore, the court said that in this instance it was not necessary to decide whether the forfeiture clause worked a "forfeiture" which the Court might have power to relieve against or whether instead there was an automatic termination of the lease since, even assuming the Court did have the power to grant relief from forfeiture, the relief would not be given because the work relied upon as "the commencement of drilling operations" was not performed with the bona fide intention to proceed thereafter with diligence.

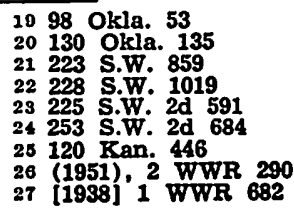


The Risvold case involved a lease which provided that the lessee was to commence drilling operations by a certain date. It also provided that time was of the essence and that a breach of any of the provisions of the lease entitled the lessor to cancel the lease. The lessee had, by the relevant date, obtained a surface lease, dug a cellar, made a contract for erecting a derrick, placed equipment on the ground and let the drilling contract. Furthermore, the lessee proceeded as diligently as possible and completed a well. The Court in holding that operations had been commenced in compliance with the lease, applied the general rule as stated by Summers. ${ }^{27 a}$ The rule quoted included the following provisions:

... actual drilling is unnecessary ... but that acts preliminary to the actual work of drilling, when performed with the bona fide intention to proceed thereafter with diligence toward completion of a well, constitute a commencement of drilling operations. If the lessee has performed such acts within the time limited and has thereafter actually proceeded with the drilling to completion, the intent with which he did the preliminary acts are unquestionable and the court may rule as matter of law that the well was commenced within the time specified in the lease.

It was also held in the Risvold case, that, under the circumstances, even if there was a breach of the provision in question, it would be relieved against because the plaintiff's inaction while defendant drilled and completed the well, in effect, worked an estoppel against him.

The doctrine of frustration or impossibility of performance prevented loss of a lease in Mercury Oils Lt. v. Vulcan-Brown Petroleum Ltd., ${ }^{28}$ where a lessee was prevented from complying with a covenant to drill a second well under the lease by reason of subsequent conservation regulations under which the lessee was refused a permit for drilling the well. Interference by the lessor with proposed drilling operations of his lessee resulting in failure of the lessee to commence drilling prevented a termination of a lease in Stevenson v. Westgate.

However, in Canada-Cities Service Oil Co. v. Kinimonth, ${ }^{29 a}$ the Alberta Court of Appeal rejected the argument of the lessee that road bans and an order of the Conservation Board had prevented it from engaging in drilling or working operations. The Court held that both the road bans and the order were not beyond the lessee's control because they should have been anticipated and avoided in advance. Accordingly, the lease was held to have terminated.

Another difficulty may arise in the operation of the "thereafter" clause where there is no market for production at the end of the primary term. A lack of market occurs most frequently where the production is natural gas of one form or another and no transportation system or refining process is available to transport it to, or make it ready for, a market. This situation was dealt with in Canadian Superior Oil of California Ltd. v. Kanstrup ${ }^{20 b}$ and in certain of the cases therein referred to. From these authorities it is clear that a lessee must scrutinize his lease very carefully before capping a well to ensure that in doing so he will not endanger the duration of the lease. Most leases attempt to avoid this problem of a shut-in or capped well by providing for a fixed royalty payment in lieu of

27 Summers on Oil and Gas, Vol. $2 \S 393$

28 [1943] S.C.R. 37

29 (1942) 1 DLR 369

$20 \mathrm{a}(1964), 47$ WWR 437, S.C.C.)

20b(1964), 47 WWR 129, (Alta. C.A.) 
an actual production royalty. ${ }^{30}$ In the Kanstrup case, however, the clause failed because it was held that it contemplated a well on the leased land whereas the only well that had been drilled was another parcel under a pooling agreement.

\section{(c) "Force Majeure" Clause}

This is the name given to the clause in a lease which provides for the extension of the lease in the event of certain unforseen or uncontrollable events occurring. These events are generally spelled out in the clause in question.

The expression "force majeure" arises from the use of that term in the Code Napoleon. It has been defined as meaning "fortuituous event", "irresistible force", or "a fact or accident which human prudence can neither foresee nor prevent". ${ }^{31}$

It is to be noted that the term differs from an Act of God as understood in the common law, in that while an Act of God is a factor giving rise to frustration of a contract as an implied term thereof,, the term "force majeure", as used in oil and gas leases, is really only a descriptive name of the clause written into the lease which states the terms upon which relief will be granted to the lessee upon the happening of certain defined events. In effect, this clause generally goes beyond what would normally be considered a "force majeure" within any of the above mentioned definitions. In fact, the "force majeure" clause usually states that it includes an incident which would be considered an Act of God at common law.

In drafting a lease the wording of this clause requires very careful consideration as is illustrated by the case of Canadian Superior Oils of California Ltd. v. Kanstrup. ${ }^{32 a}$ There the wording of the clause commenced:

All obligations under this lease requiring the lessee to commence or continue drilling or to operate on or produce oil or gas from the demised premises shall be suspended while...

It was held that the factors thereafter set forth were qualified by the proviso at the beginning of the clause, namely, "all obligations under this lease." Since the lease placed no obligation on the lessee to produce anything the clause proved to be ineffective.

With the continued increase in conservation and other governmental regulations, it would seem prudent that a "force majeure" clause should specifically cover interruption in production or other usual lessee operations by reason of the lessee's adherence to such regulations. Such a proviso should make it clear that the term of the lease should be extended for a period of time equal to the time that production has ceased due to any cause listed in the "force majeure" clause. Nonetheless, it is doubtful that such a proviso could be relied on if the only effect of the regulation

so The following clause is an example: If all wells on the said land or the pooled lands are shut-in, suspended or otherwise not producing during any year ending on an anniversary date as the result of a lack of or an intermittent market, or any cause whatsoever beyond the lessee's reasonable control, the lessee shall pay to the lessor at the expiration of each said year a sum equal to the delay rental hereinbefore set forth, and each such well shall be deemed to be a producing well hereunder.

81 Brown. The Law of Oil and Gas Leases, 236

32 Heinbigner v. Kinzel ,1931] 2 WWR 539

32a(1964), 47 WWR 129 (Alta. C.A.) 
restricting operations was to make continued production uneconomical to the lessee. ${ }^{83}$

It has been held that conditions of spring flood or heavy rain were not sufficient to bring the "force majeure" clause into play unless they were conditions which could not normally have been anticipated during that season of the year..$^{34}$

It also appears that in order for the operation of the clause to extend the primary term, the lessee must show that the well would have been drilled before the termination of the primary term but for such condition.

As a generalization, it appears that the courts are not prepared to relieve against forfeiture by application of the "force majeure" clause unless the facts come clearly within its ambit. ${ }^{35}$ Probably for this reason, a number of leases are being drawn with a default clause rather than a "force majeure" clause. Under such default clauses it is provided that the lease shall not be terminated because of default unless the lessor gives notice of the default and the lessee has not proceded to remedy it within a ninety day period. The "force majeure" proviso in the continuous drilling clause is still of value, however, for in the event that drilling beyond the primary term is held up or delayed for reasons beyond the reasonable control of the lessee it may operate to extend the lease.

\section{(d) Pooling Clause}

Although the administrative order defining drainage units or spacing units for production purposes may be scientifically sound, it is made without regard to land ownership. If a landowner's tract is less than the prescribed drainage unit, or is irregular in shape, he is prohibited from drilling and is deprived of the privilege of producing the oil under his land. Such an owner in order to take advantage of his position will be required to and may therefore, enter into an agreement for the pooling of his tract with the owners of adjacent tracts-thereby conforming to the spacing pattern for production.

Pooling and shut-in well clauses will be discussed in another paper in this issue and therefore only brief mention will be made of them. It should be noted that these clauses have been dealt with by the courts at some length, especially in Shell Oil Co. v. Gunderson, ${ }^{36}$ Shell Oil Co. v. Gibbard ${ }^{37}$ and Canadian Superior Oil of California Ltd. v. Kanstrup. ${ }^{38}$ The result has been that effective pooling and shut-in well clauses have evolved and are now in use in most current leases. The procedure under these clauses has been reasonably well defined for the working interests.

The Kanstrup case held, inter alia, that there was no obligation to pay shut-in royalty, but rather than there was an option to pay the royalty and that the effect of non-payment before the date of expiry of the primary term had the same effect as nonpayment of a delay rental-namely, an automatic termination of the lease.

Brown ${ }^{30}$ makes the following observation regarding American cases:

If a general comment can be deduced from the cases, it is that the courts recognize that pooling and unitization are both effective and economical methods of

\footnotetext{
83 Brown, The Law of Oit and Gas Leases, 239-240

84 Canadian-Cities Service Petroleum Corporation v. Kinninmonth (1964), 47 WWR 437

35 Brown, The Law of Oil and Gas Leases, 243

86 [1960], S.C.R. 424

87 [1961] SCR 725

88 (1964), 47 WWR 129

80 Brown, The Law of Oil and Gas Leases, 150
} 
producing oil and gas and that they will give effect to such agreements in cases where the language of the lease justifies it. Thus, in three out of four states where the issue has been decided it has been held that production on a unitized area which includes part of a lease will continue the entire lease in force.

As illustrated by the case referred to above, the Canadian rule is not so benevolent. Under that rule the courts appear to take a very strict view construing pooling clauses.

\section{(e) Offset Clause}

Again, this type of clause will be fully discussed in another paper of this issue. It is only intended to touch briefly on it here. Essentially, the offset requirement clause enables the lessor to demand that a well be drilled on his land; if a well is not drilled he may terminate the lease. At the same time, this clause has been further developed by the lessee to serve as a shield in protecting him from the imposition of implied covenants against drainage. In interpreting the offset clause the courts have perhaps gone too far in seeking to protect the lessor. It is difficult to find any other situation in which the provisions of a contract have been judicially interpreted in a more onerous and inflexible manner. If the basic rule in interpreting a contract is to arrive at the intention of the parties then the court's admission in Shell Oil v. Gibbard ${ }^{40}$ does it little credit.

\section{Forfeiture During the Primary Term}

It will be appreciated that the term "forfeiture" as herein discussed is not used in relation to those situations where, under an "unless" type of lease, the leasehold term comes to an end by virtue of the very words creating it, as, for example, where there has been no drilling under the lease, and rent is not paid in a year during the primary term.

A right to forfeiture of the lease may accrue to the lessor on two grounds:

(i) Breach of a covenant or condition when the lease contains an express proviso for re-entry or forfeiture consequent upon such breach.

(ii) Breach of a term of the lease which is a condition thereof.

Subject to the later comments as to provincial statutes, it is submitted that at least for the purpose of considering problems under this subtopic the common law principles of the law relating to landlord and tenant will generally apply. Proceeding on this basis it is proposed to consider the first ground of forfeiture set out above.

Halsbury ${ }^{41}$ states:

A lease may contain an express proviso for re-entry or forfeiture by the landlord on specified events ... such proviso leaves it optional with the landlord whether he will exercise his right of determining the lease upon a cause of forfeiture arising ...

The forfeiture of the lease also destroys the rights of underlessees and a breach of covenant as to part of the premises, if followed by forfeiture, will destroy an underlease of another part. 


\section{(a) Construction of Forfeiture Clauses}

In dealing with this matter Halsbury says:

The ordinary rules of construction apply ... subject to this principle, the court leans toward a literal or strict construction of a clause of forfeiture . . . it is subject to the subsidiary rule of construction that it is to be taken most strongly against the person at whose instance it is introduced, that is, the landlord.42

With respect to the breach of a term of the lease which is a condition thereof, the learned author goes on to say: "The lease will be determinable without an express proviso for re-entry if the event specified in a condition, subject to which the term was created, happens."

If, however, the clause which is put forward as ending the term constitutes only an agreement on the part of the tenant to do or not to do a specific act and is not a condition, the landlord cannot re-enter for a breach of it, except under an express proviso for re-entry. Such a condition may be express or implied and it is sufficient if the words used are intended to have the effect of creating a condition. Such words as "provided always" or "upon condition" are suitable for introducing an express condition.

Assuming that a right to terminate has or may have accrued to a lessor, what are the alternative possibilities that exist-other than for the lease to be terminated?

Because the lessor's right to effect forfeiture is optional, he can, of course, waive this right. Such waiver may be express or implied. It is implied when the lessor, after the cause of forfeiture has come to his knowledge, does any act whereby he recognizes the continuing relation of lessor-lessee. As Mr. Justice Riddell stated in Straus Land Corporation v. International Hotel: ${ }^{43}$

There has never been any doubt that a forfeiture does not act ipso facto but can be waived, and that an unequivocal act which shows a claim by the landlord of the existence of a tenancy, after the act complained of, operates as such a waiver, at least if such act be done before an unequivocal claim of forfeiture. It is needless to cite authority for this elementary proposition.

In those provinces where, as later mentioned, there may be statutes relating to landlord and tenant, in terms wide enough to include lessors and lessees in respect of oil and gas "leases", care should also be taken to consider the effect of restrictive procedures required by those statutes as a condition precedent to enforcing forfeitures.

(b) Relief Against Forfeiture

In Williams, Landlord and Tenant, ${ }^{44}$ the following general statement appears:

The courts of all provinces are by statute given powers to relieve against forfeitures and may, apart from a statute, in the exercise of their equitable jurisdiction grant equitable relief in cases where compensation can be made, or in cases where there has been fraud, accident, surprise or mistake. In some provinces the power to grant relief appears to be limited by statute.

The position as to statutory powers of relief referred to in the above quotation will probably vary in effect from province to province. No attempt is made here to give a detailed comparison of the various provincial statutes. It is noted, however, that The Landlord and Tenant

42 Id, pp. 667-8

48 (1919), 49 DLR 519 (Ont. C.A.)

44 3rd ed art. 117 
Acts of Ontario,, Manitoba ${ }^{46}$ and New Brunswick" define "lease" and "mining lease" separately. The Landlord and Tenant Act of Saskatchewan, 48 however, merely defines a "lease" in a way which includes an underlease and an agreement to lease. It does not appear otherwise to widen the ordinary meaning of lease in law and thus probably does not include a license or grant of a profit a prendre.

It is, therefore, submitted that in those cases where the provincial legislatures have specifically dealt with forfeiture under statutes relating to landlord and tenant and which apply to oil and gas "leases", the rights to relief may be broadened, but that in any other case the common law principle of equitable relief as referred to in the above quotation will govern.

The number of reported Canadian cases dealing with forfeiture of oil and gas leases appears to be few and, as might be expected in view of varying provincial statutory provisions, these few cases have not as yet satisfactorily decided the question whether the courts will grant such relief. It is submitted, however, that they generally support the proposition that relief will be given on the statutory or common law principles mentioned above, save where the breach is such that it automatically ends the leasehold term under the "unless" type of lease.

The cases which appear applicable are cited hereunder with some brief comment: In the case of Risvold v. Scott \& Granville Oils Ltd.90 the court was prepared to grant relief if necessary, but the question did not really arise as no breach of obligation was found. In Wulff v. Lundy ${ }^{\text {so }}$ the court refused to relieve against forfeiture of the lease. The members of the court varied in their reasons; two of them appeared to hold that relief could not be given against forfeiture based on the failure to drill a well where such drilling was the principle obligation of the lease and the failure could not be compensated for in damages. ${ }^{\text {00a }}$ The remaining member of the court appeared to rely on the fact that time of performance was of the essence. ${ }^{50 b}$ In the case of Wetter v. New Pacalta Oils Company Limit$e d^{31}$ the court expressed no opinion as to whether relief from forfeiture would be available, since on the facts it would not in any event have been prepared to grant it. In Oil City Petroleums Limited v. American Leduc Petroleums Limited ${ }^{32}$ all five Judges of the Alberta Appellate Court were agreed in the result of the case, but not in their reasons. Three of the Judges expressed no opinion as to the availability of forfeiture, but the remaining two considered it applicable in appropriate cases; those two concluded that there were no grounds for relief on the facts in question. In Kendal v. $S$ ith $^{53}$ the court granted relief against forfeiture.

The situation is not uncommon where, subsequent to the granting of a petroleum and natural gas lease, the lessor assigns to another party some part of his reversionary interest. It is a long standing principle that if a contract is to be rescinded, it must be rescinded as a whole and not in part.

\footnotetext{
45 R.S.O. 1960, c. 206, s. $18(1)$

46 R.S.M. 1954 , c. 136, s. $18(1)$

47 R.S.N.B. 1952 , c. 126 , s. 13

48 R.S.S. 1953 , c. 312 , s. 10

49 [1938] 1 WWR 682 (Aita.)

50 [1940] 1 WWR 444 (Alta.)

soaid at 454 .

50aid at 454

61 (1951) 2 WWR 290 (Alta.)

61 (1951) 2 WWR 371 (Alta.)

58 (1947) 2 WWR 609 (Sask.)
} 
(Sheffield Nickel Company v. Unwin ${ }^{54}$ ). It will be remendered that at common law a grantee of part of the reversion expectant on a lease could not take advantage of a breach of a condition in the lease because the condition was not divisible or apportionable. Consequently, it would appear to follow that in cases where the lessor of an oil and gas lease has assigned a part of his reversionary interest, there will be difficulty in exercising a right of forfeiture unless the reversionary part-owners are in agreement or unless the common law difficulty has been overcome by legislation. Most provinces have probably so provided by statute in respect of leases in general, ${ }^{55}$ but the question previously referred to as to whether such a statute applies to oil and gas "leases" still arises.

54 [1877] 2 Q.B.D. 214, 223.

s5 For example s. 6 of the Landlord and Tenant Act of Saskatchewan, R.S.S. 1965, Chap. 348. 